\title{
STILL MOTIVATED TO IMPROVE PERFORMANCE? A STUDY OF GOVERNMENT CONTEXT VARIABLES, DISCIPLINE, LOCAL WISDOM, WORK ENVIRONMENT AND JOB SATISFACTION AMONG CIVIL SERVANTS
}

\author{
Ahmad Yani Abdurrahman ${ }^{1)}$, H. Salim Basalamah ${ }^{2)}$, H. Syahrir Mallongi ${ }^{3)}$, Serlin Serang ${ }^{4)}$ \\ ${ }^{1)} \mathrm{PhD}$ Candidate (Muslim University of Indonesia) Makassar, Indonesia \\ ${ }^{2,3,4)}$ Lecturer in Management Science, Muslim University of Indonesia, Indonesia
}

\begin{abstract}
This study aims to examine and analyze the influence of discipline, motivation, local wisdom, and work environment on job satisfaction and employee performance. This study uses primary data through the obtained through a survey of 257 employees at the Organization of the Regional Revenue Management Area of Ternate. The result of Structural Equation Model analysis using AMOS 18 provides proof that Discipline, motivation, local wisdom, and work environment have positive and significant effect to job satisfaction. Other factors that are motivation, local wisdom, work environment and job satisfaction have positive and significant effect to employee performance, different condition for work discipline is not significant. In indirect effect test found Discipline, motivation, local wisdom, and work environment have positive and significant effect to employee performance through job satisfaction as variable intervening. The recommendation of this research is suggested that the motivation, local wisdom, and work environment that gives significant influence is maintained, while the discipline that has no significant affect on employee performance needs to be improved maximally in order to increase job satisfaction and employee performance in the future.
\end{abstract}

Keywords: Discipline, motivation, local wisdom, work environment, satisfaction, performance

\section{INTRODUCTION}

The role of local governments in the implementation of regional development should be further improved. This is intended to realize more real and responsible regional autonomy. One of the efforts to increase the role of local governments is to explore and develop potential sources of local revenue. Regional income is a regional asset that must be managed for the benefit of the government and regional development. The principle of decentralization in the implementation 
International Journal of Arts and Humanities

ISSN: 2581-3102

Volume:02, Issue:05 "May 2018"

of national and regional governments, in essence, gives authority to regions to organize Regional Autonomy within the framework of the Unitary State of the Republic of Indonesia. The organization of the regional apparatus has been faced with the demand to rationalize the organization internally according to the needs of the region and the community.

The fulfillment of targets set by the legislature is a challenge for local governments, especially the regional apparatus to be able to realize it. To meet these targets requires qualified human resources to create a Work Plan Budget (RKA) of regional apparatus organization containing revenue plans, expenditure plans, and financing plans. Own source revenue is income earned by area which is levied based on local regulation in accordance with laws and regulations. The number of regional needs can be financed by Own source revenue, the higher the level of quality of regional autonomy, also increasingly independent in the field of regional finance. Implementation of regional autonomy that is focused on the District and City Region begins with the transfer of a number of authorities (affairs) from the central government to the local government concerned (Indonesian Law 33 of 2004).

The problems faced by city government of Ternate include the limitation of development financing, in carrying out the government function as the implementer and supervisor of the development. Currently the local government is more preoccupied with the limited issue of General Allocation Fund (DAU) received. For it is shown in the following table:

Table 1: Own source revenue of Ternate City in 2012-2016

\begin{tabular}{cccc}
\hline Years & Target (Rp.) & Realization (Rp.) & Percentage (\%) \\
\hline 2012 & $38,435,000,000$ & $32,671,661,820$ & 85,00 \\
2013 & $45,535,000,000$ & $40,572,363,457$ & 89,10 \\
2014 & $52,245,000,000$ & $54,908,436,723$ & 105,10 \\
2015 & $64,650,500,000$ & $54,908,436,723$ & 89,39 \\
2016 & $70,934,252,000$ & $57,788,256,435$ & 93,21 \\
Average & $54,359,950,400$ & $48,169,831,032$ & 92,36 \\
\hline
\end{tabular}

The table explains that under the provisions in force, the realization must be in accordance with the target (limit of tolerance of 10\%).realization Own source revenue for the last five years (2012-2016) is considered to have the Own source revenue receipts not fully reach the planned target because the average realized revenue achieved is below the 90 percent threshold. This means that there is a match between the target and the realization of local revenue, especially the realization of own source revenue in 2012, 2013 and 2015 that did not reach the target. This is 
International Journal of Arts and Humanities

ISSN: 2581-3102

Volume:02, Issue:05 "May 2018"

because the government has not maximized efforts to intensify of own source revenue in Ternate City.

The optimum revenue of Own source revenue of Ternate City is caused by the lack of clarity of rules and mechanism of responsibility for the performance of activities. The accountability performance of the regional apparatus is a key to a performance-based budgeting system. Without these responsibilities, performance improvements cannot continue on an ongoing basis. Thus, without the accountability of the regional apparatus organization, the budgeting pattern has not changed and the orderly administration of regional finance cannot be realized. Although the revenue of Own source revenue in Ternate is supported by a number of (quantity) of employees who are considered adequate, but the reality of the quality has not run as expected, and it certainly affects the performance of employees of regional apparatus organizations in Ternate.

According to Gibson et al. (1994) individual performance is fundamentally influenced by factors: (1) expectations regarding rewards; (2) encouragement; (3) ability, needs and nature; (4) the perception of the task; (5) internal and external rewards; and (6) perceptions of the level of rewards and job satisfaction. The achievement of the employee performance of the organizer of the local revenue management unit of Ternate City that has not been in accordance with the expectation, certainly not apart from the influence of low job satisfaction factor, poor work discipline, inadequate motivation, unfavorable working environment, and wisdom local support. It can be seen from some aspect in general that all activities are routine, although it can be completed in accordance with the schedule specified, but the quality of employee work is not maximized due to lack of job satisfaction, lack of work discipline, lack of motivation, , and inadequate and conducive working environment. In relation to the discipline of employees of the regional apparatus organization in Own source revenue, there are still employees who are late to work or not present with unclear reasons. The low employee discipline is the large number of employees who do not return to work after lunch breaks. This shows the low discipline of employees in compliance with the rules in accordance with applicable regulations. Therefore, employee discipline needs to be studied in order to know the effect on the performance of the employees of the regional apparatus organizers of the local revenue of Ternate City

\section{LITERATURE REVIEW}

Discipline at work

Employee discipline is the obedience, diligence, diligence, and commitment of employees in providing services to the community so that the existence of discipline is an element main service that will affect the performance of employees (Musanef, 2008:18). Another view of scholars explains that discipline is the obedience of performing various ministry activities, 
International Journal of Arts and Humanities

ISSN: 2581-3102

Volume:02, Issue:05 "May 2018"

fulfilling established rules of work, being diligent in providing service, diligent in carrying out basic tasks and having a high commitment on the main task in order to improve performance (Nawawi, 2008: 82). The discipline of work is not only directed to the obedience of working hours, but also to the ability of employees to meet the demands of basic tasks and functions in accordance with the targets to be achieved by the organization as a whole. This means that employees must be able to work based on individual targets and organizational targets with the ultimate goal of achieving overall organizational performance.

Discipline at work is a form of employee self-control and regular execution and shows the level of seriousness of work teams within the organization. Thus, the discipline of work is a mental attitude reflected in the actions, individual behavior, group or society in the form of compliance or obedience to regulations established by the government or ethics, norms and rules applicable in society. Based on some of the above understanding, it can be argued that the discipline is essentially compliance with the set of rules established in an organization. Thus, it means that disciplinary rules are expected to be adhered to by employees and aimed at improving attitudes and behavior for those who violate and not on corporal punishment. The results of previous studies provide evidence that the discipline has a positive and significant effect on job satisfaction (Suyitno, 2017). The other fact, discipline has a positive and significant effect on performance (Suryono, 2017; Wulandari, 2017; Luddin \& Supriyati, 2018). The evidence is derived from other researchers, that the discipline variable has a positive not significance effect to productivity (Widodo, 2017). Discipline of work has an insignificant effect on job satisfaction of employees (Saranga et al., 2017; Duha, 2018; Hermanto, 2018).

\section{Work Motivation}

According by Gibson (1997) motivation is a force that encourages an employee who raises and directs behavior. Thus, motivation is a series of encouragement activities, not only to others but also to oneself. So that through this encouragement is expected to be able to act toward the desired goal. The power of motivation is valence and hope. Expectancy theory (Vroom, 1964, in Luthan, 2006) argues that motivation is determined by the individual's beliefs in relation to, a business relationship to performance (expectancy), the relationship between work with the results (instrumentality), and the perception of the importance of a wide variety of the work (valence). Motivation is a desire in a person that causes the person to take action. Motivation is a set of attitudes and values that affect the individual to achieve the specific in accordance with the individual goals. Such attitudes and values are an invisible one that provides the power to encourage individuals to behave in achieving their goals (Rivai, 2008: 455).

Intensity is related to how hard a person strives, and high intensity is unlikely to produce the desired performance if the effort is not channeled in the direction that benefits the organization. 
International Journal of Arts and Humanities

ISSN: 2581-3102

Volume:02, Issue:05 "May 2018"

Efforts directed toward goals and consistent with organizational goals are things that should be cultivated and therefore last a long time. Thus, motivated employees stay with their work long enough to achieve their goals (Robbins \& Judge, 2007: 213). Motivation in this study is referring to Murray quoted by Mangkunegara (2006: 69), characteristics of people who have high motivation, namely: (1) doing things as well as possible; (2) creative and innovative; (3) doing something to achieve success; (4) completing tasks that require both effort and skill; (5) always looking for something new; (6) wishing to be famous or mastering a particular field; (7) doing a difficult job with satisfactory results; (8) High work initiatives; and (9) doing something better than others. The results of previous studies provide evidence that motivation has a positive and significant effect on job satisfaction (Muslih, 2012; Dimas et al., 2015; Nurcahyani \& Adnyani, 2016; Prabowo et al., 2018; Duha, 2018). Motivation of work has a significant effect on employee performance (Kurniawan et al., 2012; Muslih, 2012; Nurcahyani \& Adnyani, 2016; Suryono, 2017; Prabowo et al., 2018). The other results proved there was no significant relationship between motivational factors (success, progress, situation, appreciation and Interest) and performance (Moradi et al., 2015).

Local wisdom

Local wisdom is the human intelligence possessed by certain ethnic groups acquired through community experience. That is, local wisdom is the result of certain communities through their experience and not necessarily experienced by other communities. These values will be attached very strongly to a particular society and that value has gone through a long time, as long as the existence of that society. Culture that includes seven elements, namely: language, knowledge system, social organization, living equipment system and technology, livelihood system, religious system, and artistry (Rahyono, 2009: 7). Wisdom should be understood in its broad sense, not only in the form of cultural norms and values, but also all elements of ideas, including those that have implications for technology, health care, and aesthetics. In that broad sense, it means that local wisdom is explained into all cultural heritages, both tangible and intangible (Sedyawati, 2007: 317).

Local wisdom is the truth that has been a tradition in an area. Local wisdom is a blend of the sacred values of God's word and various values. Local wisdom is formed as a cultural superiority of local communities and geographical conditions in a broad sense. Local wisdom is a cultural product of the past that should be constantly used as the handle of life. Although local value but the value contained in it is considered very universal. Cheung et al. (2009) shows that local wisdom in the form of supervisor-subordinate guanxi is positively related to job satisfaction. Different facts are proved in a study conducted by Zhai et al. (2013) that Supervisor-subordinate guanxi has a positive relationship with job satisfaction, although co-worker guanxi is not shown 
International Journal of Arts and Humanities

ISSN: 2581-3102

Volume:02, Issue:05 "May 2018"

related to job satisfaction. Other results indicate that as much as $40 \%$ of the variance in wisdomrelated performance is predictive of the authors' measure of wisdom-related performance. Wisdom-related performance evinced a fair degree of measurement independence (uniqueness) (Staudinger et al., 1997). Local wisdom in the form of work culture has a significant effect on employee performance (Kurniawan et al., 2012). The evidence shows that guanxi-based business variables have a profound and positive impact on firm efficiency and growth (Luo \& Chen, 1997). The results point of value the industry's prevailing environment (Pinheiro et al., 2012). Wisdom culture has effect on employees' general self-efficacy (Noruzi \& Hajipour, 2012). Local wisdom has a positive and significant effect on the infrastructure and web-based information service system. (Edy, 2017)

Work environment

Work environment is one of the factors that influence the process of activities in order to improve employee performance. Martoyo (2007: 38) explains that the working environment is the environmental condition of the creation of ideas, nuances and processes to fulfil ideas, initiatives and strategies to think work creation, work orientation, and work prospective in order to experience improvement and progress. Thus, it takes a working environment that is really conducive to creating a comprehensive work dynamics with work demands. some indicators that can be used as a measure of work environment are; lighting or workplace light, temperature or temperature at work, humidity at work, air circulation at work, excessive sound or noise at work, mechanical vibrations in the workplace (Sedarmayanti, 2008: 35). The results of previous research indicate that the environment work has a positive and significant effect on job satisfaction (Sari, 2013; Arofah et al., 2015), besides Working environment shows significant influence on employee performance (Sari, 2013: Jacobis et al. 2017).

Job Satisfaction

Basically job satisfaction is individual, because each person has a different level of satisfaction in accordance with the value system it embraces. Discussion of job satisfaction needs to be preceded by the affirmation that the problem of job satisfaction is not simple, both in terms of concept and in the sense of analysis, because job satisfaction has a diverse connotation. The more aspects of the job that suit the individual's desire, the higher the satisfaction he feels. According to Handoko (2003: 193) job satisfaction is a pleasant or unpleasant emotional state in which employees look at their work. Job satisfaction reflects a feeling of joy to his work; this is often evident in the employee's positive attitude to work and everything that is encountered in his work environment. 
International Journal of Arts and Humanities

ISSN: 2581-3102

Volume:02, Issue:05 "May 2018"

Job satisfaction in the work will be influenced by several factors, namely: working atmosphere, workplace conditions, compensation received by each employee, security in work, job status, leadership attitude towards subordinates, working time, cooperation in work, clear division of tasks, old age guarantees, success in performing tasks, and the relevance between talents and interests with the field of duty (Toban \& Sjahruddin, 2016). If the factors that affect a job above have a positive impact, then someone will experience satisfaction in carrying out his work. Although the problem of satisfaction is relative to every person, but if it can be utilized the opportunity that there is minimal work and do not feel depressed, it can ultimately ensure the survival of the organization (Mangkunegara, 2000: 19). Empirical evidence shows that job satisfaction has a significant and positive effect on performance (Sari, 2013, Melina \& Intan, 2012; Nurcahyani \& Adnyani, 2016; Wulandari, 2017; Prabowo et al., 2018; Luddin \& Supriyati, 2018). The evidence is derived from other researchers, that job satisfaction has no significant effect on performance (Suryono, 2017).

\section{Employee Performance}

Employee performance can be improved through improvement of work discipline, and work motivation and work environment, because with a conducive working environment, and high work discipline will be able to increase the spirit, willingness, and accuracy of employees at work will be more leverage, and focus (Damayanti \& Sumaryati, 2013). Understanding the performance is basically the activities and results that can be achieved or continued a person or group of people in the implementation of tasks, work well, meaning to achieve the target or work standards that have been set before and or even exceed the standards determined by the company in a certain period (Handoko, 2003: 139).

Performance is the result of work in quality and quantity achieved by employees in carrying out tasks in accordance with the responsibilities given by superiors (Prawirosentono, 1999; Hasanuddin \& Sjahruddin, 2017). The results of previous research indicate that intrinsic and extrinsic motivations have an indirectly significant effect on employee performance through job satisfaction (Muslih, 2012). Different results on the support of job satisfaction in explaining the influence of discipline on performance, that job satisfaction is able to mediate the influence of the discipline on the performance of employees (Wulandari, 2017; Suryono, 2017). Job satisfaction is the partially mediated influence of work motivation toward employee performance (Prabowo et al., 2018).

\section{METHODS}

This research is an explanatory research used to find and explain the causal relationship between variables through hypothesis testing. Therefore, the approach explanatory research to study this 
International Journal of Arts and Humanities

ISSN: 2581-3102

Volume:02, Issue:05 "May 2018"

issue is deemed appropriate and appropriate (Nazir, 2013). The population in this research is 718 employees who work in 13 offices of regional organization of local revenue organizer of Ternate City. Determination of sample using Slovin formulation so that the sample as many as 257 employees. Provide the hypothesis is done by using a structural equation modeling (SEM) with AMOS assistance 21

\section{RESULTS}

Based on the data in the Table, it can be explained that the respondent's education level which occupy the highest proportion is high school counted 91 people $(35,41 \%)$. These results indicate that the level of education of employees at the organization of the Regional Device Revenue Manager of Ternate Municipal Region is quite adequate because almost half of the employees have the level of education Bachelor. An adequate level of education is expected to create a good performance. However, it is realized that the level of education is not the only factor that determines the performance of a person, because high school-educated employees may perform better than higher-educated employees.

Table 2: The main characteristics of the sample

\begin{tabular}{lcc}
\hline Characteristics & Frequency & Percent $(\%)$ \\
\hline Gender & & \\
$\quad$ Male & 135 & 52,53 \\
$\quad$ Female & 122 & 47,47 \\
Age & & \\
$\quad \leq 33$ Years & 16 & 6,23 \\
$34-39$ Years & 125 & 48,64 \\
$40-45$ Years & 65 & 25,29 \\
$\geq 46$ Years & 51 & 19,84
\end{tabular}

Job tenure

$\leq 11$ Years

13,62

12- 17 Years

$\geq 18$ Years

28,79

Education level

High School

Associate's degree

Bachelor degree

Master degree

9

Doctoral degree

0,39

Note ( $n=257$ ) 
International Journal of Arts and Humanities

ISSN: 2581-3102

Volume:02, Issue:05 "May 2018"

Test results for the model based on the goodness of fit indices in table 3 shows the criteria for a model seen meet the conformance testing data

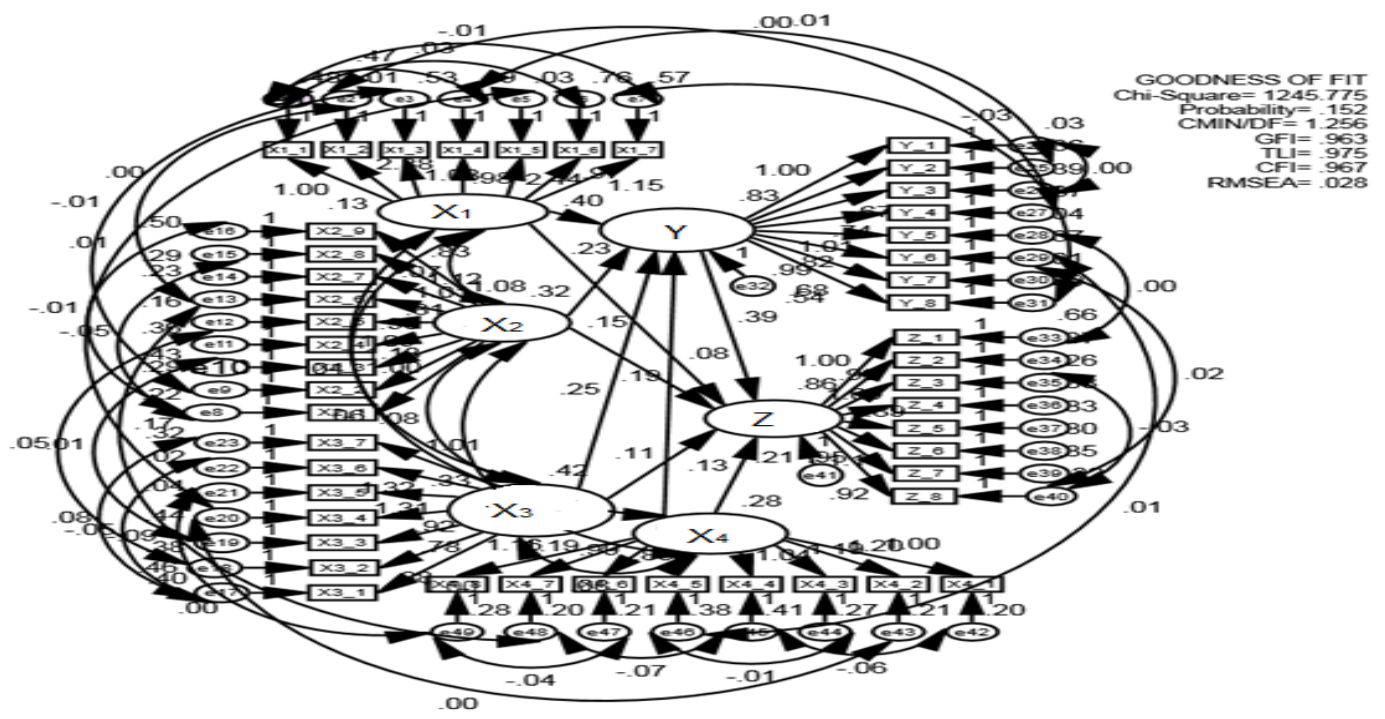

Fig. 1: Goodness of Fit Overall Model

Table 3: Goodness of Fit Overall Model

\begin{tabular}{cccc}
\hline Goodness of fit index & Cut-off Value & Results Model * & Remarks \\
\hline$\chi^{2}-$ Chi-square & Expected to be & $124,577(0,05: 309=350,996)$ & Good \\
& Small & 0.152 & Good \\
Probability & $\geq 0.05$ & 1.256 & Good \\
CMIN/DF & $\leq 2.00$ & 0.028 & Good \\
RMSEA & $\leq 0.08$ & 0.963 & Good \\
GFI & $\geq 0.90$ & 0.967 & Good \\
CFI & $\geq 0.94$ & 0.975 & Good \\
TLI & $\geq 0.94$ & &
\end{tabular}

Based on the empirical model, it can be tested against the hypothesis proposed through the testing of the path coefficients in the structural equations model. 
International Journal of Arts and Humanities

ISSN: 2581-3102

Volume:02, Issue:05 "May 2018"

Table 4: Hypothesis testing

\begin{tabular}{cccccc}
\hline $\begin{array}{c}\text { Relationship } \\
\text { between } \\
\text { variables }\end{array}$ & p-value & $\begin{array}{c}\text { Standardized } \\
\text { Regression Estimates }\end{array}$ & CR & Remarks \\
\hline X1 & Y & 0,005 & 0,176 & 2,789 & Significant \\
& Z & 0,389 & 0,046 & 0,861 & Insignificant \\
X2 & Y & 0,000 & 0,154 & 4,142 & Significant \\
& Z & 0,000 & 0,132 & 3,721 & Significant \\
X3 & Y & 0,001 & 0,191 & 3,231 & Significant \\
& Z & 0,040 & 0,109 & 2,051 & Significant \\
X4 & Y & 0,000 & 0,123 & 3,335 & Significant \\
& Z & 0,001 & 0,111 & 3,199 & Significant \\
Y & Z & 0,000 & 0,508 & 7,203 & Significant
\end{tabular}

Effect of discipline at work $\left(\mathrm{X}_{1}\right)$ on job satisfaction $(\mathrm{Y})$

The value of regression coefficient effect of discipline on job satisfaction is a 0.176 . This shows that the better discipline will increase job satisfaction by the value of regression coefficient of discipline that is equal to 0.176 (other variable fixed). The hypothesis states that the discipline variable has a positive and significant effect on job satisfaction. This result shows the value is critical ratio obtained at 2.789 and the significance level is $0.005<0.05$, so the hypothesis can be accepted or proven. Discipline and job satisfaction have a positive and significant causal relationship. The positive effect of the discipline variable on job satisfaction is determined by the strong desire of within the employee in complying with the rules and the prevailing rules. The desire from within the employee resulted in high job satisfaction felt by employees. This result is relevant to the study conducted by Suyitno (2017) that the discipline has a positive and significant effect on job satisfaction. The findings derive from other researchers' argument that the discipline of work has an insignificant effect on job satisfaction of employees (Saranga et al., 2017; Duha, 2018; Hermanto, 2018).

Effect of work motivation $\left(\mathrm{X}_{2}\right)$ on job satisfaction $(\mathrm{Y})$

The value of regression coefficient effect of work motivation on job satisfaction is a 0,154 . This shows that the better motivation will increase job satisfaction equal to the value of regression coefficient motivation that is equal to 0,154 (other variable remain). The hypothesis states that motivation variables have a positive and significant effect on job satisfaction. These results indicate that the value critical ratio is 4.142 and the significance level is $0.000<0.05$, so the 
International Journal of Arts and Humanities

ISSN: 2581-3102

Volume:02, Issue:05 "May 2018"

hypothesis can be accepted or proven because the employee is able to perform the job properly, so that the impact on the improvement of employee job satisfaction. The results of previous studies provide evidence that motivation has a positive and significant effect on job satisfaction (Muslih, 2012; Dimas et al., 2015; Nurcahyani \& Adnyani, 2016; Prabowo et al., 2018; Duha, 2018). The results obtained a rebuttal from other researchers that motivation has positive and insignificant effect on job satisfaction (Basuki \& Maesaroh, 2017; Afiyah et al., 2017).

Effect of local wisdom $\left(\mathrm{X}_{3}\right)$ on job satisfaction $(\mathrm{Y})$

The value of regression coefficient effect of local wisdom on job satisfaction is a 0.191 . This shows the better local wisdom will increase job satisfaction. The hypothesis states that local wisdom variables have positive and significant impact on job satisfaction. These results indicate that the value is critical ratio obtained at 3.231 and the significance level is $0.001<0.05$, so the hypothesis can be accepted or proven. Attention employees to the implementation of work in detail and complex resulting in high job satisfaction perceived employees. The results of this study support the findings of a study conducted by Cheung et al. (2009) proves that local wisdom in the form of supervisor-subordinate guanxi is positively related to job satisfaction. Different facts are proved in a study conducted by Zhai et al. (2013) that Supervisor-subordinate guanxi has a positive relationship with job satisfaction, although co-worker guanxi is not shown related to job satisfaction.

\section{Effect of work environment $\left(\mathrm{X}_{4}\right)$ on job satisfaction $(\mathrm{Y})$}

The value of regression coefficient effect of work environment on job satisfaction is a 0.123 . This shows that the better working environment will increase job satisfaction. The hypothesis states that the work environment variables have a positive and significant effect on job satisfaction. This result shows that the value is critical ratio obtained at 3.335 and the significance level is $0.000<0.05$, so the hypothesis can be accepted or proven. Properly adjusted air-conditioned workplace temperatures make employees comfortable so employees feel satisfied at work. This study supports the results of research which explains that the work environment has a positive and significant impact on job satisfaction (Sari, 2013; Arofah et al., 2015). The findings were denied by Afiyah et al. (2017) that the working environment not significant effect on job satisfaction

Effect of discipline at work $\left(\mathrm{X}_{1}\right)$ on employee performance $(\mathrm{Z})$

The value of regression coefficient effect of discipline on employee performance is a 0,046 . This shows that the discipline variable has an insignificant effect on employee performance because the value is critical ratio obtained only 0.861 and the required significance level of $0.389>0.05$. Thus, the hypothesis which expresses the discipline variable has a positive and significant effect 
International Journal of Arts and Humanities

ISSN: 2581-3102

Volume:02, Issue:05 "May 2018"

on employee performance, so the hypothesis is rejected or unproven. This study is relevant to the findings (Widodo, 2017) that the discipline variable has a positive not significance effect to productivity. This study differs from the findings of other researchers that the discipline has a positive and significant effect on performance (Suryono, 2017; Wulandari, 2017; Luddin \& Supriyati, 2018).

Effect of work motivation $\left(\mathrm{X}_{2}\right)$ on employee performance $(\mathrm{Z})$

The value of regression coefficient effect of work motivation on employee performance is a 0.132 . This shows the better motivation will improve employee performance. The hypothesis states that the motivation variable has a positive and significant effect on the performance of the employees. This result shows that the critical ratio value is 3.721 and the significance level is $0.000<0.05$, so the hypothesis can be accepted or proven. This evidence is relevant to the findings of previous researchers that work motivation significantly affects employee performance (Kurniawan et al., 2012; Muslih, 2012; Nurcahyani \& Adnyani, 2016; Suryono, 2017; Prabowo et al., 2018). The other results proved there was no significant relationship between motivational factors (success, progress, situation, appreciation and Interest) and performance (Moradi et al., 2015).

Effect of local wisdom $\left(\mathrm{X}_{3}\right)$ on employee performance $(\mathrm{Z})$

The value of regression coefficient effect of local wisdom on employee performance equal to 0,109 . This shows that the better local wisdom will improve the employee performance. The hypothesis states that local wisdom variables have a positive and significant effect on employee performance. These results indicate that thevalue is critical ratio obtained at 2.051 and the significance level is $0.040<0.05$, so the hypothesis is acceptable or proven. This study supports the findings by Pinheiro et al. (2012) the results point to the conclusion that companies with high organizational wisdom do manage to improve their efficiency and effectiveness but this proves insufficient for actually increasing the level of value created when taking into account the industry's prevailing Environment. Wisdom culture has effect on employees' general self efficacy (Noruzi \& Hajipour, 2012). Local wisdom has a positive and significant effect on the performance of the tourism business to be moderated by the effect of supporting infrastructure and web-based information service system. Indicators of local knowledge of the most dominant influence on business performance is the government, education, the diversity of the Community (Edy, 2017)

Effect of work environment $\left(\mathrm{X}_{4}\right)$ on employee performance $(\mathrm{Z})$

The value of regression coefficient effect of work environment on employee performance is a 0.111. This shows that the better working environment will improve the performance of 
International Journal of Arts and Humanities

ISSN: 2581-3102

Volume:02, Issue:05 "May 2018"

employees. The hypothesis states that the work environment variables have a positive and significant effect on employee performance. These results indicate that the value is critical ratio obtained at 3.199 and the significance level is $0.001 \leq 0.05$, so the hypothesis can be accepted or proven. This result is relevant to the findings of some earlier researchers that the work environment showed a significant effect on employee performance (Sari, 2013: Jacobis et al., 2017).

Effect of job satisfaction (Y) on employee performance (Z)

The value of regression coefficient effect of job satisfaction on employee performance is a 0.508 . This shows the increasing job satisfaction will improve employee performance. The hypothesis states that job satisfaction variables have a positive and significant effect on employee performance. This result shows the value critical ratio is 7,203 and the significance level is $0.000<0,05$, so the hypothesis can be accepted or proven. The results of this study are relevant to the findings of other researchers that job satisfaction has a significant and positive effect on performance (Sari, 2013; Melina \& Intan, 2012; Nurcahyani \& Adnyani, 2016; Wulandari, 2017; Prabowo et al., 2018; Luddin \& Supriyati , 2018). Such evidence obtained denials from other researchers, that job satisfaction has no significant effect on performance (Suryono, 2017)

Effect of discipline at work on employee performance through job satisfaction

The test results show that the direct effect between disciplines with employee performance is 0,046 and the indirect effect through job satisfaction with positive direction equal to 0,089 , while total effect which is sum of direct effect and indirect effect through job satisfaction is 0,136 . Test results show that the level of significance $p$-value $=0.229>0.05$. The supporting of job satisfaction in this test has not been able to increase the contribution of work discipline to the performance of employees. This study differs from other scholarly findings that job satisfaction is able to mediate the influence of discipline on the performance of employees (Wulandari, 2017; Suryono, 2017).

Effect of work motivation on employee performance through job satisfaction

The test results show that the direct effect between work motivation with employee performance is 0.132 , and the indirect effect value through job satisfaction is 0,078 , while the total effect which is the sum of the direct effect and indirect effect through job satisfaction obtained of 0.210. This means that the impact of variables intervening can strengthen the relationship between motivation and employee performance supported by facts and empirical data. The test results show that the significance level $p$-value $=0.007<0.05$. The supporting of job satisfaction in this test proved able to increase the contribution of work motivation to employee performance. This study has similarities by Prabowo et al. (2018) that job satisfaction is the partially mediated 
International Journal of Arts and Humanities

ISSN: 2581-3102

Volume:02, Issue:05 "May 2018"

influence of work motivation toward employee performance. Intrinsic and extrinsic motivations have an indirectly significant effect on employee performance through job satisfaction (Muslih, 2012).

Effect of local wisdom on employee performance through job satisfaction

The test results show that the direct effect between local wisdom with employee performance is 0.109. The indirect effect through job satisfaction with a positive value of 0.097 , while the total effect which is the sum of direct effects and indirect effects through job satisfaction obtained of 0.205. This means that the impact of variables intervening can strengthen the relationship between local wisdom and employee performance supported by facts and empirical data. The test results show that the significance level of p-value $=0.015<0.05$. The supporting of job satisfaction in this test proved able to increase the contribution of local wisdom to the performance of employees.

Effect of work environment on employee performance through job satisfaction

The test results show that the direct effect between work environments with employee performance is 0,111 and the indirect effect through job satisfaction with a positive value of 0.062, while the total effect which is the sum of direct effects and indirect effects through job satisfaction obtained of 0.173 . This means that the impact of variables intervening can strengthen the relationship between work environment and employee performance supported by facts and empirical data. The test results show that the significance level of $\mathrm{p}$-value $=0.015<0.05$. Support Job satisfaction in this test proved able to improve the contribution of work environment to employee performance.

\section{CONCLUSION}

The application of discipline, work motivation, local wisdom and work environment provides enhancement to the effort of creating perceived job satisfaction. On the other hand, employees who are disciplined in working are not able to have a real effect on employee performance. Motivation, local wisdom, work environment and job satisfaction proved able to improve employee performance. The role of job satisfaction as a mediation variable is evident in explaining the contribution of work motivation, local wisdom and work environment to employee performance but the condition does not occur in the work discipline. The existence of different sample characteristics in this study, which does not distinguish between employees with the leadership so it is feared there it is can be different levels of understanding and knowledge in understanding the problem. 
International Journal of Arts and Humanities

ISSN: 2581-3102

Volume:02, Issue:05 "May 2018"

\section{REFERENCES}

[1] Afiyah, SN, Djaelani, AQ, \& Priyono, AA (2017). Effect of compensation, work environment and motivation on employee job satisfaction (Case Study at National Land Agency of Malang Regency). Journal of Scientific Research Management, 6 (2).

[2] Arofah, S., Fathoni, A., \& Minarsih, MM (2015). Effect of Compensation, Expertise and Work Environment on Employee Job Satisfaction at Bank Permata Bangkong Branch Semarang. Journal of Management, 1 (1).

[3] Basuki, K., \& Maesaroh, M. (2017). Motivation as a mediator of the influence of commitment and work environment on job satisfaction. Business Management Journal, 13 (1).

[4] Cheung, MF, Wu, WP, Chan, AK, \& Wong, MM (2009). Supervisor-subordinate guanxi and employee work outcomes: The mediating role of job satisfaction. Journal of Business Ethics, 88 (1), 77-89.

[5] Damayanti, AP, \& Sumaryati, S. (2013). Influence of Compensation and Work Motivation on Employee Performance of Drinking Water Company (PDAM) of Surakarta. Jupe-Journal of Economic Education, 2 (1).

[6] Dimas, ID, Rebelo, T., \& Lourenço, PR (2015). Learning conditions, members' motivation and satisfaction: a multilevel analysis. The Learning Organization, 22 (2), 131-147.

[7] Duha, T. (2018). Lecturer Job satisfaction by discipline and motivation mediated by organizational commitment. Journal of Application Management, 16 (2), 300-308.

[8] Edy, IC (2017). Investigating The Impact of Local Wisdom on The Performance of Business Tourism. International Journal of Multidisciplinary Approach \& Studies, 4 (2).

[9] Gibson, James L. (1997). Organization. Jakarta: Erlangga

[10] Gibson, James L., John M. Ivancevich \& James H. Donnelly, Jr. (1996). Organization, Behavior, Structure, Process, (Interpreting Nunuk Adiarni), Publisher Binarupa Aksara, Jakarta.

[11]Handoko, T.Hani. (2003). Personnel and Human Resource Management. Yogyakarta, BPFE-Yogyakarta.

[12]Hasanuddin, R., \& Sjahruddin, H. (2017). The Structure of Emotional Intelligence, Spiritual Intelligence and Its Relationship with Work Enthusiasm and Auditor Performance. World Journal of Business and Management, 3 (1), 67.

[13]Hermanto, H. (2018). The Influence Of Giving Incentives And The Application Of Work Discipline To The Working Satisfaction Of Permanent Employees In The Office Of Pajarakan Sub District, Probolinggo. International Journal of Social Science and Business, 2 (1), 10-20.

[14] Jacobis, GV, Kojo, C., \& Wenas, RS (2017). The influence of individual characteristics and work environment on the performance of employees in the environmental department of the 
International Journal of Arts and Humanities

ISSN: 2581-3102

Volume:02, Issue:05 "May 2018"

province of North Sulawesi. Journal of EMBA: Journal of Economic, Management, Business and Accounting Research, 5 (2).

[15] Kurniawan, D., Lubis, AR, \& Adam, M. (2012). The influence of work culture and work motivation on employee performance International Federation Red Cross (IFRC) Banda Aceh. Journal of Management Science ISSN, 2302, 0199.

[16]Luddin, MR, \& Supriyati, Y. (2018). Influence of Work Discipline, Career Development and Job Satisfaction on Employee Performance Directorate General Research and Development of Ministry of Research, Technology and Higher Education. International Journal of Scientific Research and Management, 6 (02).

[17]Luo, Y., \& Chen, M. (1997). Does guanxi influence firm performance ?. Asia Pacific Journal of Management, 14 (1), 1-16.

[18]Luthans, Fred. (2006). Organizational behavior. Edition 10. Yogyakarta

[19] Mangkunegara, AA Anwar Prabu. (2006). Planning and Development. Human Resource Management. Bandung: PT. Refika Aditama

[20] Mangkunegara, Anwar Prabu. (2000). Human Resource Management. Company, Second edition. PT. Remaja Rosda Karya, Bandung

[21] Martoyo, S. (2007). Human Resource Management. Yogyakarta: BPFE-. Yogyakarta

[22] Melina Taurisa, C., \& Intan, R. (2012). Analysis of the influence of organizational culture and job satisfaction on organizational commitment in improving employee performance (Study at PT Sido Muncul Kaligawe Semarang). Journal of Business and Economics, 19(2).

[23] Moradi, M., Shekarchizadeh, AR, \& Nili, M. (2015). Determination of Factors that Affect on Motivation and Assessing their Impact on Employee Performance. Research Journal of Recent Sciences

[24] Musanef. (2008). Indonesian Personnel Management. Volume II, Jakarta: PT Gunung Agung.

[25] Muslih, B. (2012). Analysis of the influence of motivation on job satisfaction and employee performance in PT Sang Hyang Seri (Persero) Regional III Malang. Journal of Application Management, 10 (4), 799-810.

[26] Nawawi, Hadari. (2008). Human Resource Management. Jakarta: Ghalia . Indonesia

[27] Nazir, Moh. (2013). Research methods. Jakarta: Balai Aksara

[28] Noruzi, MR, \& Hajipour, E. (2012). A study on the Relationships between wisdom Cultural and Employees' public relations efficacy of employees in Islamic Azad University branches in Locale 13. Nigerian Chapter of Arabian Journal of Business and Management Review, 62 (1084), 1-9.

[29] Nurcahyani, Ni Made., \& Adnyani, IGAD (2016). The effect of compensation and motivation on employee performance with job satisfaction as intervening variable. E Journal of Management Unud, 5. 
International Journal of Arts and Humanities

ISSN: 2581-3102

Volume:02, Issue:05 "May 2018"

[30] Pinheiro, P., Raposo, M., \& Hernández, R. (2012). Measuring organizational wisdom applying an innovative model of analysis. Management Decision, 50 (8), 1465-1487.

[31] Prabowo, TS, Noermijati, N., \& Irawanto, DW (2018). The Influence of transformational leadership and work motivation on employee performance mediated by job satisfaction. Journal of Application Management, 16 (1), 171-178.

[32] Prawirosentono. S, (1999). Human Resource Management, Employee Performance Policy. BPFE, Yogyakarta.

[33] Rahyono, FX (2009). Wisdom of the Natural Culture Words, Jakarta: Wedatama Widya Sastra.

[34]Republic of Indonesia. (2004). Law Number 33 Year 2004 regarding Fiscal Balance between Central Government and Local Government.

[35] Rivai, Veithzal. (2008). Human Resource Management for Companies .PT.Raja Grafindo Persada: Jakarta.

[36] Robbins, Stephen P. \& Judge, Timothy A. (2007). Organizational Behavior, book 2. Jakarta: Salemba Empat

[37] Saranga, O., Budiyanto, B., \& Khuzaini, k. (2017). The influence of individual capability, work discipline and work environment toward the employee satisfaction with career development as the mediation. Journal of Business and Management, 19 (8), 6-11.

[38] Sari, FM (2013). The influence of competence and work environment to job satisfaction and performance of teachers in SD Negeri Gondang Subdistrict Mojokerto. DIE, 9(2).

[39] Sedarmayanti. (2008). Human Resource Management, Bandung: PT. Refika Aditama

[40] Sedyawati, Edi. (2007). Indonesian in Culture: The First Book. The Need to Build a Powerful Nation. Jakarta: Wedatama Widya Sastra.

[41] Staudinger, UM, Lopez, DF, \& Baltes, PB (1997). The psychometric location of wisdomrelated performance: intelligence, personality, and more? Personality and Social Psychology Bulletin, 23 (11), 1200-1214.

[42] Soriano, T. (2017). Influence leadership, organizational culture, discipline, compensation against satisfaction, employee motivation and performance (Study on population and civil registry office of Surakarta). eAbstract Excellent, 3 (2).

[43] Suyitno, S. (2017). Effect of competence, satisfaction and discipline on the performance of employees in the office of women empowerment and family planning of West Papua. Asian Social Science, 13 (5), 144

[44]Toban, C., \& Sjahruddin, H. (2016). The Antecedent and Consequence of Organizational Commitment and Job Satisfaction. Journal of Business and Management Sciences, 4 (2), 2633. 
[45]Widodo, H. (2017). Effect of competence, working environment, discipline and teacher training on productivity with satisfaction and motivation as an intervening variable (Case Study on SMK Negeri 2 Wonogiri). eAbstract Excellent, 2 (2).

[46] Wulandari, RW (2017). Effect of competence, commitment and job satisfaction against discipline and performance at the department of public works and energy and mineral resources boyolali. eAbstract Excellent, 2 (2).

[47]Zhai, Q., Lindorff, M., \& Cooper, B. (2013). Workplace guanxi: Its dispositional antecedents and mediating role in the affectivity-job satisfaction relationship. Journal of Business Ethics, 117 (3), 541-551. 